\title{
GAMBARAN FREKUENSI INCOMPATIBLE AUTO CONTROL PADA PENDERITA TALASEMIA DENGAN TRANSFUSI BERULANG $<10$ DAN $\geq 10$ DI RUMAH SAKIT HERMINA JATINEGARA
}

\author{
*Lenggo Geni' ${ }^{1)}$, Atna Permana, ${ }^{1)}$, Wiwin Widayanti ${ }^{2}$ \\ ${ }^{1}$ Program Studi Analis Kesehatan, Fakultas Kesehatan, Universitas Mohammad Husni Thamrin \\ ${ }^{2} \mathrm{RS}$ Hermian Jatinegara \\ Correspondence author: Lenggo Geni, Lenggogeni19@gmail.com, Jakarta, Indonesia
}

\begin{abstract}
ABSTRAK
Transfusi darah adalah suatu tindakan memindahkan komponen darah yang ditranfusikan ke tubuh resipien. Pada penderita Talasemia mempunyai kadar hemoglobin kurang dari normal, maka dibutuhkan transfusi berulang. Penatalaksanaan transfusi sangat penting untuk menghindari efek dari transfusi berulang, berupa reaksi segera sampai reaksi tunda, jenisnya reaksi imun atau non imun. Hingga terbentuk antibodi pada sel darah merah menyebabkan Incompatible auto control pada Uji Silang Serasi. Penelitian ini dilakukan di Bank Darah Rumah Sakit Hermina Jatinegara periode Januari 2018 - Mei 2018. Bertujuan melihat gambaran Uji Silang Serasi dengan hasil Incompatible Auto Control yang menggunakan transfusi berulang pada 79 penderita Talasemia beta mayor. Teknis analisa data yang digunakan analisis persentase. Hasil penelitian menunjukan Gambaran frekuensi Incompatibel auto control pada penderita Talasemia beta mayor dengan transfusi berulang $<10$ kali memiliki hasil yang signifikan yaitu $8 \%$ lebih rendah dibandingkan dari transfusi berulang $\geq 10$ yaitu 52 $\%$. Disarankan mengunakan pendonor tetap untuk transfusi berulang pada penderita Talasemia untuk menurangi paparan antigen, mengurangi terbentuknya antibodi yang masuk kedalam tubuh dan transfusi lebih aman.
\end{abstract}

Kata kunci : Talasemia,Transfusi berulang

\section{ABSTRACT}

Blood transfusion is an act of moving the blood components that are transfused into the recipient's body. Thalassemia sufferers have hemoglobin levels less than normal, so repeated transfusions are needed. Transfusion management is very important to avoid the effects of repeated transfusions, in the form of immediate reactions to delayed reactions, whether they are immune or nonimmune reactions. Until antibodies are formed on red blood cells, it causes Incompatible auto control in the Serasi Cross Test. This research was conducted at the Blood Bank of Hermina Jatinegara Hospital for the period January 2018 - May 2018. Aims to see the description of the Cross Test with Incompatible Auto Control results using repeated transfusions on 79 patients with beta thalassemia major. The data analysis technique used is percentage analysis. The results showed that the frequency of auto control incompatibilities in patients with beta thalassemia major with repeated transfusions $<10$ times had a significant result that was $8 \%$ lower than those from repeated transfusions $\geq 10$, namely $52 \%$. It is advisable to use regular donors for repeated transfusions in thalassemia patients to reduce exposure to antigens, reduce the formation of antibodies that enter the body and make transfusions safer.

Keyword : Thalassemia, repeated transfusions. 


\section{PENDAHULUAN}

Talasemia merupakan penyakit kelainan genetik yang diwariskan dari kedua orang tua sejak lahir. Gejala penyakitnya adalah anemia, Pembengkakan limpa dan hati, perubahan bentuk tulang muka dan warna kulit menjadi hitam. Keadaan ini akan menjadi lebih parah apabila tidak dikendalikan. Berdasarkan data dari Yayasan Talasemia Indonesia, jumlah kasus penyakit Talasemia sebanyak 8.011 pada Mei 2017 meningkat dari tahun 2015 yang berjumlah 7.029 kasus (Sulistyowati,L. 2017).

Talasemia merupakan kelompok kelainan yang diturunkan karena terjadi mutasi atau delesi pada gen yang kehilangan salah satu rantai globulin sehingga terjadi penurunan kecepatan sintetsis, atau ketiadaan sintesis, dari rantai yang setara. Pada Talasemia ringan (Thalassemia Triat), sumsum tulang dapat mengimbangi dengan memproduksi eritrosit lebih banyak sehingga terjadi mikrositosis tanpa anemia. Pada Talasemia yang lebih berat, terjadi anemia dan pada Talasemia paling berat dapat bersifat fatal atau selama hidupnya bergantung pada transfusi darah berulang (Bain, B. J. 2017: 49).

Talasemia beta mayor adalah gangguan genetik sentesis hemoglobin yang ditandai dengan tidak adanya atau berkurangnya sentesis rantai globin. Sehingga mengakibatkan kekurangan deposit hemoglobin dan pada eritrosit (hipokromatik), dan ditemui kadar hemoglobin di bawah batas normal, sehingga membutuhkan transfusi darah selama hidupnya (Nesya,S. 2011).

Transfusi darah adalah suatu tindakan memindahkan darah atau komponen darah dalam sistem pembuluh darah seseorang. Komponen yang biasa ditransfusikan ke dalam tubuh resipien adalah eritrosit, trombosit, plasma, dan lekosit. Transfusi darah rutin dilakukan pada resipien yang memiliki kelainan darah sebagai terapi yang bertujuan menggantikan atau menambah komponen darah yang hilang. Transfusi darah pada penderita Talasemia sangat diperlukan dikarenakan kebanyakan dari penderita Talasemia mempunyai kadar hemoglobin kurang dari normal, berupa transfusi Packed Red Cell (PRC) atau Washed Eritrosit (Isnanos, 2011).

Tindakan transfusi darah merupakan tindakan medis yang sering dilakukan pada penderita Talasemia, karena hal ini merupakan tindakan yang paling sederhana dan tidak terlalu sulit dibandingkan dengan pencangkokan sumsum tulang belakang. Tetapi tindakan ini mengandung resiko yang sangat berbahaya. Maka penatalaksanaan transfusi sangat penting guna menghindari hal tersebut (Pardiyah, 2011).

Transfusi berulang bisa mengakibatkan efek samping berupa reaksi segera sampai reaksi tunda, dengan kategori rekasi imun atau non imun. Salah satu efek dari transfusi berulang yang sangat mungkin terjadi adalah penimbunan zat besi pada jaringan, survival sel darah merah sangat pendek, terbentuknya antibodi terhadap trombosit dan antibodi terhadap lekosit (Ritchie, 2009).

Open Journal System (OJS): journal.thamrin.ac.id 
Petugas unit transfusi darah atau petugas Bank darah mempunyai peranan yang sangat penting untuk meminimalisir keadaan tersebut dengan melakukan pemeriksaan uji Silang Serasi dan uji Screening antibody untuk menghindari hal yang tidak diinginkan (Panduan Bank Darah, 2016).

Uji silang serasi adalah reaksi silang invitro antara darah resipien dengan darah donor sebelum ditransfusikan. Pada prinsipnya transfusi darah merupakan suatu tindakan transplantasi organ, sehingga darah yang diberikan dapat bertahan dalam tubuh resipien dan memberikan manfaat klinis, serta dapat mengetahui ada tidaknya antibodi komplit (tipe $\operatorname{IgM}$ ) maupun antibodi inkomplit (tipe $\operatorname{IgG}$ ) dalam serum resipien yang disebut uji silang serasi mayor, dan dalam serum donor yang disebut uji silang serasi minor (Isnanos, 2011).

Uji silang serasi (Mayor Cross Matching) untuk mengetahui adanya antibodi di dalam darah resepien terhadap eritrosit donor. Mayor Cross Matching positif sangat berbahaya, karena di dalam darah resepien terdapat banyak antibodi yang mampu melisiskan eritrosit donor yang berada dalam tubuh resepien. Minor Cross Matching untuk mengetahui adanya antibodi di dalam darah donor terhadap eritosit resipien. Minor Cross Matching positif tidak terlalu berbahaya karena antibodi dari donor masuk ke dalam tubuh penderita, tetes demi tetes, sehingga segera dapat diencerkan oleh darah resipein (Pardiyah, 2011:3).

Kesalahaan menyimpulkan hasil uji silang serasi akan berakibat fatal, sehingga digunakan uji Screening antibody dengan metode gel tes, untuk mendeteksi dan mengidentifikasi kelompok antibodi tak terduga pada sel panel jenis Rhesus, Kell, Duffy, Kidd, MN, Ss, P, Lewis (Irregular Antibody). Bila terdapat salah satu jenis ini maka hasil Screening antibody Incompatible. Pada Talasemia beta mayor transfusi berulang dapat ditemukan hasil uji silang serasi Incompatible atau tidak cocok pada Auto Control positif, sehingga akan terjadi reaksi antigen antibodi baik Invivo yang terbentuk karena infeksi, alergi, autoimun dan reaksi yang paling sering timbul adalah pecahnya eritrosit (hemolisis) (Hippy, N.S.I 2008:17).

Penderita Talasemia Beta Mayor di Rumah sakit Hermina Jatinegara membutuhkan transfusi secara rutin seumur hidupnya. Penggunaan darah dalam waktu 5 bulan ada yg kurang dari 10 kali, sama dengan 10 kali atau lebih dari 10 kali transfusi. Sebagian penderita ada yang mengalami sensitisasi invivo oleh Immune antibody IgG akibat dari transfusi yang dilakukan. Sehingga menyebabkan hasil dari uji silang serasi pada Auto Control menjadi Incompatible.

Berdasarkan latar belakang, peneliti ingin mengetahui adanya antibodi yang ditimbulkan akibat transfusi berulang yang dilakukan pada penderita Talasemia beta mayor. Hal tersebut dilakukan dengan melihat hasil reaksi Incompatible Auto Control pada hasil uji silang serasi dan uji Screening antibody. 


\section{METODE}

Populasi penelitian adalah penderita Talasemia beta mayor yang melakukan rawat inap dan menjalankan tindakan transfusi darah berulang $<10$ kali atau $\geq 10$ kali di Rumah Sakit Hermina Jatinegara, baik laki - laki maupun perempuan pada penderita Talasemia beta mayor. Sampel diambil dari data pemerikasaan uji silang serasi pada 79 penderita Talasemia beta mayor di Rumah Sakit Hermina Jatinegara periode bulan Januari 2018 - Mei 2018 yang melakukan transfusi berulang yang menggunakan darah PRC Leukodepleted. Data - data yang diperoleh dari penelitian dihitung presentase sampel yang Incompatible auto control terhadap seluruh sampel.

\section{HASIL \& PEMBAHASAN}

Berdasarkan data hasil pemeriksaan Incompatible Auto Control pada penderita Talasemia beta mayor di Rumah Sakit Hermina Jatinegara priode Januari 2018 - Mei 2018. Jumlah seluruh penderita Talasemia beta mayor yang melakukan transfusi berulang adalah 79 penderita. Hasil distribusi Frekuensi transfusi pada penderita Talasemia beta mayor berdasarkan jenis kelamin dapat dilihat pada tabel 1.

Tabel 1.

Distribusi Frekuensi Hasil Uji Silang Serasi berdasarkan Jenis Kelamin pada penderita Talasemia beta mayor di RS Hermina Jatinegara

\begin{tabular}{cccccccc}
\hline \multirow{2}{*}{ Jenis Kelamin } & \multirow{2}{*}{$\begin{array}{c}\text { Jumlah } \\
\text { Penderita }\end{array}$} & \multicolumn{2}{c}{ Compatible } & \multicolumn{2}{c}{ Incompatible } & \multirow{2}{*}{ Total } \\
\cline { 3 - 6 } & 32 & 25 & $\mathbf{F}$ & $\mathbf{F}$ & $\mathbf{\%}$ & & \\
\hline Laki - laki & $37 \%$ & 7 & $22 \%$ & 32 & $100 \%$ \\
\hline Perempuan & 47 & 29 & $62 \%$ & 18 & $38 \%$ & 47 & $100 \%$ \\
\hline Total & $\mathbf{7 9}$ & $\mathbf{5 4}$ & $\mathbf{6 8 \%}$ & $\mathbf{2 5}$ & $\mathbf{3 2 \%}$ & $\mathbf{7 9}$ & $\mathbf{1 0 0 \%}$ \\
\hline
\end{tabular}

Sumber primer dan sekunder 2018

Dari tabel 4 diketahui pada penderita perempuan didapatkan hasil Compatible sebesar $62 \%$ dan Incompatible auto control sebesar 38\%. Sedangkan pada penderita Talasemia beta mayor laki laki didapatkan hasil uji silang serasi, Compatible sebesar 78\% dan Incompatible auto control sebesar $22 \%$.

Data hasil pemeriksaan Incompatible Auto Control pada penderita Talasemia beta mayor di RS. Hermina Jatinegara, dapat dilihat berdasarkan kategori usia data dapat dilihat pada tabel 2. 
Tabel 2.

Distribusi Frekuensi Hasil Uji Silang Serasi berdasarkan Kategori Usia Penderita Talasemia beta mayor di RS Hermina Jatinegara

\begin{tabular}{cccccccc}
\hline $\begin{array}{c}\text { Kategori } \\
\text { Usia }\end{array}$ & $\begin{array}{c}\text { Jumlah } \\
\text { Penderita }\end{array}$ & \multicolumn{2}{c}{ Compatible } & \multicolumn{2}{c}{ Incompatible } & \multirow{2}{*}{ Total } \\
$\begin{array}{c}\text { Balita }(0- \\
5)\end{array}$ & 19 & 16 & $84 \%$ & 3 & $16 \%$ & 19 & $100 \%$ \\
\hline $\begin{array}{c}\text { Anak } \\
(>5-10)\end{array}$ & 17 & 14 & $82 \%$ & 3 & $18 \%$ & 17 & $100 \%$ \\
\hline $\begin{array}{c}\text { Remaja } \\
(>10-17)\end{array}$ & 24 & 18 & $75 \%$ & 6 & $25 \%$ & 24 & $100 \%$ \\
\hline $\begin{array}{c}\text { Dewasa } \\
(>17)\end{array}$ & 19 & 6 & $32 \%$ & 13 & $68 \%$ & 19 & $100 \%$ \\
\hline Total & $\mathbf{7 9}$ & $\mathbf{5 4}$ & $\mathbf{6 8 \%}$ & $\mathbf{2 5}$ & $\mathbf{3 2 \%}$ & $\mathbf{7 9}$ & $\mathbf{1 0 0 \%}$ \\
\hline
\end{tabular}

Sumber primer dan sekunder 2018

Dari tabel 2 didapat hasil pada balita usia 0 sampai 5 tahun Compatible sebesar $84 \%$ dan Incompatible auto control sebesar 19\%, pada anak-anak usia lebih dari 5 tahun sampai 10 tahun, didapat hasil uji silang serasi Compatible sebesar $82 \%$ dan Incompatible auto control sebesar 18\%, pada remaja usia lebih dari 10 sampai 17 dengan hasil Compatible sebesar 75\% dan hasil Incompatible auto control sebesar 25\%, sedangkan pada penderita dewasa dengan usia lebih dari 16 tahun hasil uji silang serasi Compatibel sebesar 68\% dan hasil Incompatible sebesar $32 \%$

Dan dilihat berdasarkan data hasil pemeriksaan uji silang serasi pada penderita Talasemia beta mayor yang mendapat transfusi berulang dapat dilihat pada tabel 2 .

Tabel 3.

Distribusi Frekuensi Hasil UJi Silang Serasi pada penderita Talasemia beta mayor dengan Transfusi berulang

\begin{tabular}{cccccccc}
\hline $\begin{array}{c}\text { Jumlah } \\
\text { Transfusi } \\
\text { (kali) }\end{array}$ & $\begin{array}{c}\text { Jumlah } \\
\text { Penderita }\end{array}$ & $\mathbf{F}$ & $\mathbf{\%}$ & $\mathbf{F}$ & $\mathbf{\%}$ & \multirow{2}{*}{ Total } \\
\cline { 5 - 6 } & 37 & 34 & $92 \%$ & 3 & $8 \%$ & 37 & $100 \%$ \\
\hline$<10$ & 42 & 20 & $48 \%$ & 22 & $52 \%$ & 42 & $100 \%$ \\
\hline$\geq 10$ & $\mathbf{7 9}$ & $\mathbf{5 4}$ & $\mathbf{6 8 \%}$ & $\mathbf{2 5}$ & $\mathbf{3 2 \%}$ & $\mathbf{7 9}$ & $\mathbf{1 0 0 \%}$ \\
\hline Total & & & & & & \\
\hline
\end{tabular}


Sumber data primer 2018

Transfusi berulang $<10$ kali didapatkan nilai Compatible $92 \%$ dan hasil Incompatible auto control sebesar $8 \%$. Sedangkan pada penderita yang mendapat transfusi $\geq 10$ kali didapatkan nilai Compatible $48 \%$ dan Incompatible auto control sebesar 52\%.

Dari data tabel 1 didapat hasil yang signifikan bahwa penderita Talassemia beta mayor lebih banyak dialami oleh perempuan dibandingkan laki - laki. Hal ini tidak sesuai dengan kompas.com penderita Talassemia pada yayasan Talasemia Indonesia, yang berobat dipusat Talasemia RSCM hingga juli 2008 mencapai 1.412 orang. Sebanyak 775 penderita penyakit adalah laki-laki. Hasil penelitian Rejeki dkk. (2012), yang menyatakan bahwa, baik laki-laki ataupun perempuan, adalah sama-sama dapat menderita Talasemia. Tidak ada kaitannya dengan jenis kelamin dengan transfusi berulang yang dilakukan penderita Talasemia.

Pada penderita Talasemia beta mayor laki - laki diketahui nilai Incompatible auto control lebih rendah dibanding penderita perempuan. Hal ini dapat disebabkan oleh faktor usia, berat badan, kadar hemoglobin sehingga dibutuhkan transfusi berulang, pada penderita perempuan yang sudah mengalami mentruasi dibutuhkan lebih banyak dibanding dengan penderita laki, sehingga lebih membutuhkan transfusi berulang $\geq 10$ kali. Transfusi berulang memungkinkan terbentuknya antibodi karena sering mengalami paparan antigen. Maka uji silang serasi didapatkan hasil Incompatible auto control. Antibodi yang dibentuk berupa antibodi IgG dan Complemen pada eritrosit penderita.

Talasemia dapat diderita mulai dari balita sampai dewasa. Hal ini sesuai dengan penelitian yang didapatkan pada balita $16 \%$, anak $18 \%$, remaja $25 \%$ dan dewasa $68 \%$. Bila dilihat dari kategori usia pada balita, didapatkan hasil Incompatible auto control yang merupakan hasil paling rendah, hal ini dimungkinkan pada balita penggunaan jumlah transfusi kurang 10 kali, sehingga masih sedikit terkena paparan antigen. Pada anak- anak hasil Incompatibel auto control lebih besar dari balita, dan pada remaja hasil Incompatibel auto control lebih besar dari anak-anak, sedangkan pada penderita dewasa hasil Incompatibel auto control menunjukan ada peningkatan dari balita sampai dewasa. Pada penderita dewasa lebih banyak membutuhan transfusi dibandingkan dengan penderita balita, anakanak maupun remaja. Karena kebutuhan untuk transfusi pada anak-anak dan penderita dewasa berbeda.

Hasil penelitian transfusi berulang $<10$ kali hasil Compatible sebesar 92 dan Incompatible 8\%. Sedangkan transfusi berulang $\geq 10$ kali hasil Compatible 48\% dan Incompatibel 52\%. Dari data hasil yang didapat laki - laki dan perempuan Pada penderita Talasemia beta mayor dan dari kategori usia, yang melakukan transfusi berulang kurang dari 10 dan ada yang sama atau lebih dari 10 kali. Ditemukan penderita hasil signifikan sebesar 92\% dengan hasil Compatibel dan sebesar 8\% dengan hasil Incompatible, pada transfusi kurang dari 10 kali. Sedang Pada penderita Talasemia beta mayor 
yang melakukan transfusi sama dengan atau lebih dari 10 kali didapat hasil Compatibel sebesar 48\% dan hasil Incompatibel sebesar 52\%.

Hasil penelitian ini tidak sesuai dengan penelitian sebelumnya yang dilakukan oleh Pardiyah (2011) menyatakan hasil Incompatibel pada transfusi yang kurang dari 10 kali sebesar $0 \%$ dan pada transfusi lebih dari 10 kali didapat hasil Incompatibel sebesar 51\%. Hal ini kemungkinan disebabkan oleh antibody dapat terbentuk dikarenakan kedua kalinya terpaparan dengan antigen dari darah pendonor yang masuk ketubuh penderita. Faktor - faktor yang mempengaruhi reaksi hemolitik adalah jenis antibodi, spesifisitas antibodi, suhu reaksi antibodi, aktivasi komplemen, titer antibodi, volume sel eritrosit yang ditransfusikan.

Dan salah satu bentuk reaksi transfusi berulang dapat berupa reaksi imun dan non imun. Reaksi imun yang terjadi bisa berupa reaksi hemolitik, yang dapat menyebabkan reaksi yang bersifat kuat terjadi tidak lama setelah darah ditransfusikan (reaksi Incompatibilitas) dan dapat menyebabkan kematian. Gejala klinis yang ditimbulkan mulai dari adanya rasa seperti terbakar ditempat transfusi, demam, menggigil, rasa sakit dipunggung belakang sampai pinggang. Maka disarankan mengunakan pendonor tetap (donor keluarga), untuk transfusi berulang pada penderita Talasemia agar menurangi paparan antigen dan mengurangi terbentuknya antibodi yang masuk kedalam tubuh penderita. Transfusi yang dilakukan jauh lebih aman.

\section{SIMPULAN}

Gambaran frekuensi Incompatible auto control pada penderita Talasemia beta mayor dengan transfusi berulang $<10$ kali sebesar $8 \%$ dan transfusi berulang $\geq 10$ sebesar $52 \%$.

\section{UCAPAN TERIMA KASIH}

Penulis mengucapkan terima kasih kepada Kepala Laboratorium RS Hermina Jatinegara dan Prodi D III Analis Kesehatan Fakultas Kesehatan Universitas MH Thamrin. dalam penelitian ini.

\section{DAFTAR PUSTAKA}

1. Bain, Bj.” Hematologi Kurikulum Inti.” EGC. Jakarta 2014.

2. Diamed a Division of Biord." Skor Kekuatan Reaksi.

3. Harti,AS." Imunologi Dasar dan Imunologi Klinis." GRAHA ILMU Yogyakarta 2013.

4. Hippy, NSI." Perbandingan teknik Tabung Dengan Gel Pada pemeriksaan Uji Silang Serasi." Jakarta 2008

5. Hofibrand,AV dan Moss, DAH." Kapita Selektra Hematologi." EGC Jakarta 2013.

6. Isnanos."Referat Transfusi Darah," Jakarta 2011.

7. Kiswari, R." Hematologi dan Trasnfusi." Erlangga semarang - Jawa Tengah 2014.

Open Journal System (OJS): journal.thamrin.ac.id

http://journal.thamrin.ac.id/index.php/anakes/issue/view/34 
8. Nesya, S.” Referat Talasemia” Jakarta 2011

9. Panduan Bank Darah Revisi 1 Jakarta 2016.

10. Pardiyah." Hubungan Transfusi darah berulang dengan uji silang serasi pada penderita Thalasemia." Semarang 2011

11. Rejeki, DSS, dkk." Model Prediksi Kebutuhan Darah Untuk Penderita Talasemia Mayor." Jawa Tengah 2012

12. Rithchie, NK." Pengolahan Kompoden darah.” WORKSHOP Jakarta 2009

13. Rithchie, NK." Sistem dan Imunologi Golongan Darah.” WORKSHOP Jakarta 2009

14. Rithchie, NK." Transfusion RISK and Complication." WORKSHOP Jakarta 2009

15. Subowo." Imunologi EDISI 3." Sagung Seto Jakarta 2014

16. Waluyo L. Teknik dan metode dasar dalam mikrobiologi. Malang: Universitas Muhammadiyah Malang; 2008.

17. Http://www.donor darah.info 2017

18. Http://www.depkes.go.id/article/view/18050800002/hari-Thalasemia-sedunia-2018bersama-untuk-masa-depan-yang-lebih-baik-html.

19. Https://ipp.go.id/humaniora/kesehatan/305025/pengidap_thalasemia_di_Indonesia-capai8011-kasus (Sulistyowati 2017)

20. Http://en.wikipedia.org/wiki/ABO-blood-group-sistem

21. Https://lifestyle.kompas.com/read/2009/04/10/1614258/thalasemia meningkat tiap tahu $\underline{\mathrm{n}}$ 